Dariusz Pożaroszczyk

Agencja Bezpieczeństwa Wewnętrznego

d.pozaroszczyk@op.pl

\title{
Odpowiedzialność dyscyplinarna funkcjonariuszy służb specjalnych w świetle koncepcji rzetelnego procesu na przykładzie reżimu dyscyplinarnego Agencji Bezpieczeństwa Wewnętrznego
}

\author{
Disciplinary procedure in the Polish Special Services in the light of the idea of fair \\ trial,using the disciplinary procedure of the Internal Security Agency as an example
}

\begin{abstract}
The incentive for contributing this paper is the planned great reform of the Polish Special Services. The study attempts to formulate some requirements that should be met by disciplinary procedure. This goal is achieved by analysing the effective disciplinary procedure in the Internal Security Agency (ABW), the largest branch of the Polish Special Services, in the prism of the idea of fair trial. The assessment conducted of the disciplinary procedure in ABW, leads to the conclusion that the effective law has many shortcomings. Major drawbacks are lack of establishment in respect the supreme rule of disciplinary procedure and lack of clear definition in the application of the general rules of criminal law within the domain of disciplinary procedure. The paper concludes that the shortfalls illustrated, should be eliminated as fast as possible in order to adjust the disciplinary regime to modern standards.
\end{abstract}

Keywords: disciplinary procedure, special services, fair trial

Słowa kluczowe: postępowanie dyscyplinarne, służby specjalne, rzetelny proces

Służby specjalne są szczególnymi instytucjami w państwie demokratycznym. Charakter i ciężar zadań powierzonych służbom implikuje wyposażenie ich w szereg uprawnień, korzystanie z których łączy się z istotną ingerencją w prawa i wolności obywatelskie. Równocześnie wyznaczone na płaszczyźnie ustawowejzadania służb specjalnych powodują, iż w trakcie wykonywania czynności funkcjonariusze tych instytucji spotykająsięz najgroźniejszymi przejawami przestępczości,za którymi nierzadko stoją zorganizowanegrupy przestępcze, a czasami (jak w przypadku szpiegostwa) nawetobce 
i wrogie państwa. Powyższe fakty powodują, iż realizując czynności operacyjno-rozpoznawcze oraz procesowe, funkcjonariusze służb specjalnych poddani są niezwykle silnej i zróżnicowanej presji. W skrajnych przypadkach presja ta prowadzić może do sprzeniewierzenia się składanemu ślubowaniu i ostatecznie skutkować łamaniem prawa, niewłaściwym wykonywaniem powierzonych obowiązków bądź zachowaniami sprzecznymi z etyką zawodową.

Wskazane wyżej okoliczności powodują, iż kwestia zachowania dyscypliny i poszanowania przepisów prawa przez funkcjonariuszy służb ma niezwykle istotne znaczenie. Jednym z podstawowych mechanizmów, który służy zabezpieczeniu praworządności w obszarze służb, są przepisy kreujące reżim odpowiedzialności dyscyplinarnej ${ }^{1}$. Normy dyscyplinarne muszą być tak zredagowane, by utworzony przez nie model odpowiedzialności był sprawnym i skutecznym instrumentem wzmacniającym praworządność w działaniu służb. Równocześnie przewidziane rozwiązania muszą respektować generalne zasady obowiązujące w demokratycznym państwie prawa.

W ostatnim okresie media informują o planach głębokiej reformy służb specjalnych ${ }^{2}$. W związku z tymi zamierzeniami rzeczą potrzebną wydaje się być analiza obowiązujących przepisów dyscyplinarnych, które dotyczą największej służby specjalnej, jaką jest Agencja Bezpieczeństwa Wewnętrznego (dalej jako ABW). Analiza ta ma na celu zwrócenie uwagi na istniejące niedoskonałości obecnej regulacji reżimu dyscyplinarnego, tak aby mankamenty te mogły zostać usunięte w przepisach dotyczących nowych służb.

W aktualnym stanie prawnym odpowiedzialność dyscyplinarna właściwa dla ABW określona została w rozdziale 10 ustawy z dnia 24 maja 2002 r. o Agencji Bezpieczeństwa Wewnętrznego oraz Agencji Wywiadu ${ }^{3}$. Kwestie szczegółowe o charakte-

1 Ze względu na realizowane przez służby specjalne funkcje i posiadane uprawnienia kwestia kontroli nad tymi instytucjami jest zagadnieniem o szczególnym znaczeniu w demokratycznym państwie prawa. Obowiązujący obecnie w Polsce model kontroli służb specjalnych jest systemem wielopodmiotowym i wielowymiarowym. Kompetencje kontrolne nad działalnością operacyjną i procesową służb specjalnych powierzone zostały różnym podmiotom, które wykonują swoje czynności w zakresie odmiennych aspektów działalności służb specjalnych. Część podmiotów kontrolnych i realizowanych przez nie mechanizmów ma charakter wewnętrzny i usytuowana jest w obrębie danej służby - takim charakterem odznacza się niewątpliwie system odpowiedzialności dyscyplinarnej. Więcej o kontroli służb specjalnych zob.: A. Taracha, Czynności operacyjno-rozpoznawcze aspekty kryminalistyczne i prawnodowodowe, Lublin 2006, s. 292-317; J. Gryz, Teoretyczne aspekty funkcjonowania służb specjalnych RP, „Studia i materiały” 2012, nr 1, s. 86; D. Pożaroszczyk, Prawne mechanizmy służące zapewnieniu przestrzegania praworządności w wojskowych służbach specjalnych, (w:) M. Karpiuk, M. Czuryk (red.), Prawo wojskowe, Warszawa 2015, s. 271-284. Zagadnieniu kontroli nad służbami specjalnymi w perspektywie międzynarodowej poświęcona jest praca W.K. Smidt, U. Poppe, W. Krieger, H. Müller-Enbergs (red.), Geheimhaltung und Transparenz: demokratische Kontrolle der Geheimdienste im internationalen Vergleich, Berlin - Münster 2007.

2 Wydaje się, że w chwili obecnej konkurują dwa rozwiązania: pierwsze zakłada połączenie ABW z AW i stworzenie Agencji Bezpieczeństwa Narodowego, drugie wcielenie wszystkich służb specjalnych do nowego Ministerstwa Ochrony Państwa, zob. http://www.gazetaprawna.pl/artykuly/995010,kaminski-zreformuje-sluzby-specjalne-ministerstwo-ochrony-panstwa.html (data dostępu: 26.11.2016 r.).

3 Ustawa z dnia 24 maja 2002 r. o Agencji Bezpieczeństwa Wewnętrznego oraz Agencji Wywiadu (tekst jedn. Dz.U. z 2015 r. poz. 1929 ze zm.). 
rze proceduralnym zawarte są natomiast w rozporządzeniu Prezesa Rady Ministrów z dnia 20 grudnia 2004 r. w sprawie udzielania wyróżnień i przeprowadzania postępowań dyscyplinarnych wobec funkcjonariuszy Agencji Bezpieczeństwa Wewnętrznego ${ }^{4}$. W obliczu takiego stanu pierwszym wymogiem, jaki winien być postawiony przed przepisami dotyczącymi nowej służby specjalnej, jest postulat zaprzestania regulowania kwestii dotyczących odpowiedzialności dyscyplinarnej w akcie podustawowym ${ }^{5}$. Za słusznością uregulowania prawa dyscyplinarnego aktem ustawowym przemawia fakt, że choć reżim dyscyplinarny nie kreuje odpowiedzialności o charakterze stricte karnym, to jednak stanowi jej swoiste uzupełnienie i wzmocnienie, potwierdzając okoliczność, iż zjawisko karania nie ogranicza się do sfery państwowego prawa karnego ${ }^{6}$. Odpowiedzialność dyscyplinarna jest niewątpliwie odpowiedzialnością represyjną ${ }^{7}$. Przepisy dyscyplinarne bezsprzecznie nakładają na podlegające im osoby określone ciężary i tym samym mogą skutkować ograniczeniem praw i wolności obywatelskich. Niektóre z sankcji dyscyplinarnych swoją surowością istotnie przekraczają dolegliwość kar i środków karnych przewidzianych w kodeksie karnym $^{8}$. Równocześnie $\mathrm{w}$ demokratycznym państwie prawnym każda regulacja normatywna, która umożliwia ingerencję w prawa i wolności obywatelskie, musi mieć status ustawy. Wyraźnie i jednoznacznie stanowi o tym art. 31 ust. 1 Ustawy Zasadniczej, który stwierdza, że ograniczenia w zakresie korzystania z konstytucyjnych wolności i praw mogą być ustanawiane tylko w ustawie.

Kolejny problem dotykający obowiązujących przepisów dyscyplinarnych właściwych dla ABW to brak określenia nadrzędnej zasady, na której opiera się odpowiedzialność dyscyplinarna funkcjonariuszy. Pominięcie wskazania zasady konstrukcyjnej prawa dyscyplinarnego w przepisach właściwych dla ABW i określenie jedynie przesłanek tej odpowiedzialności ${ }^{9}$, którymi w świetle art. 144 i 145 u.ABW są popełnienie przestępstwa bądź wykroczenia oraz naruszenia dyscypliny służbowej,

4 Rozporządzenie Prezesa Rady Ministrów z dnia 20 grudnia 2004 r. w sprawie udzielania wyróżnień i przeprowadzania postępowań dyscyplinarnych wobec funkcjonariuszy Agencji Bezpieczeństwa Wewnętrznego (tekst jedn. Dz.U. z 2014 r. poz. 60).

5 Taki sam postulat formułuje S. Maj, Odpowiedzialność dyscyplinarna w służbach mundurowych. Możliwość uchwalenia wspólnej procedury, (w:) P. Jóźwiak, K. Opaliński (red.), Węzłowe problemy prawa dyscyplinarnego w służbach mundurowych. Il seminarium z cyklu „Odpowiedzialność dyscyplinarna w służbach mundurowych”, „Biblioteczka Kwartalnika Prawno-Kryminalistycznego” 2012, nr 2, s. 40 i 42 . W tym kierunku szedł również, nieuchwalony ostatecznie, projekt nowej ustawy o ABW, zob. Projekt ustawy o ABW z dnia 1 sierpnia 2013 r., s. 86, dostępny na stronie internetowej http://bip.msw.gov.pl/bip/projekty-aktow-prawnyc/2013/22385,Projekt-ustawy-o-Agencji-Bezpieczenstwa-Wewnetrznego.html (data dostępu: 26.11.2016 r.).

$6 \quad$ Warto w tym miejscu przywołać pogląd M. Cieślaka, który prawo dyscyplinarne uznawał za szczególną gałąź bądź rodzajową odmianę prawa karnego, M. Cieślak, Polskie prawo karne. Zarys systemowego ujęcia, Warszawa 1994, s. 22-23.

7 L. Gardocki, Prawnokarna problematyka sędziowskiej odpowiedzialności dyscyplinarnej, (w:) J. Giezek (red.), Przestępstwo - kara - polityka kryminalna. Problemy tworzenia i funkcjonowania prawa. Księga jubileuszowa z okazji 70. rocznicy urodzin Profesora Tomasza Kaczmarka, Kraków 2006, s. 191, zob. też Wyrok WSA w Poznaniu z dnia 1 kwietnia 2009 r., IV SA/Po 475/08, Lex 533530.

$8 \quad$ P. Jóźwiak, Instytucja ułaskawienia - refleksje na płaszczyźnie odpowiedzialności dyscyplinarnej w służbach mundurowych, (w:) P. Jóźwiak, K. Opaliński (red.), Węzłowe problemy..., op. cit., s. 29-33.

9 O rozróżnieniu między zasadą odpowiedzialności a jej przesłankami zob. A. Brzozowski, M. Safjan, E. Skowrońska-Bocian, Zobowiązania, Warszawa 2004, s. 206-207. 
a także inne przypadki określone w ustawie, nasuwa pytanie, czy odpowiedzialność dyscyplinarna właściwa dla ABW jest oparta na zasadzie winy, czy też jest to odpowiedzialność zobiektywizowana oparta na cywilistycznych konstrukcjach ryzyka lub słuszności ${ }^{10}$. W tym miejscu należy wskazać, że odpowiedzialność dyscyplinarna w służbach mundurowych wprost na zasadzie winy oparta została w ustawach o Policji ${ }^{11}$, o Państwowej Straży Pożarnej oraz o Służbie Więziennej ${ }^{12}$. Wobec powyższych rozwiązań brak określenia w art. 144 i 145 obecnie obowiązującej ustawy o ABW oraz AW zasady, na której opiera się odpowiedzialność dyscyplinarna skłania do przyjęcia, że odpowiedzialność dyscyplinarna funkcjonariuszy ABW jest niezależna od winy, a więc posiada status odpowiedzialności obiektywnej, nakładającej określone, negatywne konsekwencje jedynie w oparciu o zaistnienie związku przyczynowego pomiędzy zachowaniem człowieka a zaistniałym skutkiem. Uzasadnienia dla przyzwolenia, by odpowiedzialność dyscyplinarna w ABW opierała się na zasadzie obiektywnej, szukać można w chęci zaostrzenia przepisów dyscyplinarnych, motywowanej argumentem, że charakter zwalczanych zagrożeń i wyznaczone zadania, których realizacja ma fundamentalne znaczenie dla bezpieczeństwa Polski, przesądzają o tym, iż odpowiedzialność w strukturach ABW winna być odpowiedzialnością surowszą niż odpowiedzialność policjantów, strażaków czy funkcjonariuszy Służby Więziennej. Nie negując potrzeby istnienia szczególnie silnej dyscypliny w służbach specjalnych, zauważyć jednak należy, że celowościowo uzasadniona wykładnia, zezwalająca by w ramach reżimu dyscyplinarnego dochodziło do obiektywnego przypisania skutku, z przyczyn aksjologicznych jest całkowicie nie do zaakceptowania. Wskazane już zostało, że odpowiedzialność dyscyplinarna jest odpowiedzialnością represyjną, która nakłada na podlegające jej osoby określone ciężary z istoty swej wkraczające w sferę konstytucyjnie chronionych praw i wolności. Ingerencje, które wynikają z zastosowania reżimu dyscyplinarnego, tak jak sankcje karne dotykają praw najbardziej osobistych. Fakt ten jednoznacznie przemawia za poddaniem odpowiedzialności dyscyplinarnej oddziaływaniu zasady winy. W wyroku z dnia 19 marca 2007 r., wydanym w związku z ograniczeniami prawa do obrony Trybunał Konstytucyjny ${ }^{13}$ jednoznacznie stwierdził, że: ,,art. 42-45, a także art. 78 Konstytucji znajdują zastosowanie do oceny nie tylko regulacji o stricte karnym charakterze, lecz także odpowiednio do innych regulacji o represyjnym charakterze, w tym do odpowiedzialności dyscyplinarnej. Ustawodawca ma obowiązek takiego ukształtowania przepisów regulujących wszelkiego rodzaju postępowania dyscyplinarne, by - tak jak w postępowaniu karnym - zapewniały odpowiedni poziom prawa do obrony $\mathrm{w}$ wymiarze materialnym

\footnotetext{
10 Należy podkreślić, że w obszarze prawa cywilnego w związku z odpowiedzialnością ex deliktu odwołanie do zasad ryzyka i słuszności pełni rolę uzupełniającą. Zasadą naczelną reżimu odpowiedzialności z tytułu czynu niedozwolonego jest zasada winy, co jednoznacznie wyraża art. 415 kc. Zob. więcej A. Brzozowski, M. Safjan, E. Skowrońska-Bocian, op. cit., s. 206-208.

11 Ustawa z dnia 6 kwietnia 1990 r. o Policji (tekst jedn. Dz.U. z 2016 r. poz. 1782).

12 Ustawa z dnia 9 kwietnia 2010 r. o Służbie Więziennej (Dz.U. z 2016 r. poz. 713).

13 Wyrok TK z dnia 19 marca 2007 r., K 47/05 (Dz.U. z 2007 r. nr 57, poz. 390).
} 
i formalnym"14. W przywołanym wyroku, odwołując się do zasady proporcjonalności, Trybunał Konstytucyjny wskazał również, że: „,w wypadku służb mundurowych (jak i w innych wypadkach) ograniczenie praw jednostki musi mieć odpowiednie uzasadnienie, innymi słowy musi być proporcjonalne”. W obliczu przywołanego orzeczenia represyjny charakter odpowiedzialności funkcjonariuszy ABW przesądza, iż do odpowiedzialności tej zastosowanie muszą mieć fundamentalne dla całego prawa represyjnego gwarancje i zasady, w tym zasada winy ${ }^{15}$. W związku $\mathrm{z}$ tym, oceniając prawo dyscyplinarne właściwe dla ABW, stwierdzić należy, że brak jednoznacznego uregulowania kwestii zasady konstrukcyjnej odpowiedzialności stanowi niewątpliwie mankament obecnie obowiązującej ustawy. Oceny tej nie zmienia treść $\$ 28$ ust. 1 rozporządzenia Prezesa Rady Ministrów z dnia 20 grudnia 2004 r. określająca okoliczności, które winny być uwzględnione przy wymiarze kary dyscyplinarnej oraz w przypadku odstąpienia od jej wymierzenia. Przepis ten wyraźnie wskazuje stopień winy jako jedną z okoliczności, którą należy uwzględniać w związku z wymierzeniem kary dyscyplinarnej. Rozwiązanie to czyni zadość standardom współczesnego prawa represyjnego przyjmującego, że surowość kary dyscyplinarnej nie powinna przekraczać stopnia winy. Tylko kara współmierna do stopnia winy, uwzględniająca całą złożoność sytuacji, w której doszło do popełnienia czynu rodzącego odpowiedzialność dyscyplinarną, wymierzona w oparciu o analizę wszystkich okoliczności przemawiających zarówno za zaostrzeniem, jak i złagodzeniem odpowiedzialności, może być uznana za karę sprawiedliwą. Wskazanie winy jako okoliczności, którą należy brać pod uwage przy wymiarze kary, nie jest jednak jednoznaczne z oparciem reżimu dyscyplinarnego na zasadzie indywidualnej odpowiedzialności oraz zarzucalności, i jako takie jest niewystarczające. Biorąc pod uwagę, iż jednoznaczność zasady winy jako podstawy odpowiedzialności dyscyplinarnej w świetle wykładni literalnej, systemowej i historycznej wcale nie jest oczywista, a równocześnie uwzględniając fakt, że ze względów gwarancyjnych oparcie odpowiedzialności dyscyplinarnej jest możliwe jedynie na tej zasadzie, kwestia zasady konstrukcyjnej prawa dyscyplinarnego winna być uregulowana jednoznacznie.

Brak jednoznacznego oparcia reżimu dyscyplinarnego właściwego dla ABW na zasadzie winy łączy się w sposób naturalny z brakiem ustosunkowania się do fundamentalnej zasady współczesnego prawa karnego, jaką stanowi zasada domniemania niewinności ${ }^{16}$. Zasada domniemania niewinności uważana jest za immanentny element demokratycznego państwa prawnego i łączy się z wyrażoną w art. 30 Kon-

14 Identyczne stanowisko w przedmiocie obowiązywania w ramach reżimu dyscyplinarnego wszystkich gwarancji przewidzianych w rozdziale drugim Ustawy Zasadniczej zajął TK w wyroku z dnia 8 grudnia 1998 r., K 41/97 (Dz.U. z 1998 r. Nr 158, poz. 1043).

15 Zob. też D. Korczyński, Wina jako przesłanka odpowiedzialności dyscyplinarnej funkcjonariuszy służb mundurowych, (w:) P. Jóźwiak, K. Opaliński (red.), Węzłowe problemy..., op. cit., s. 14 i 30.

16 Domniemanie niewinności jako standard prawa dyscyplinarnego wskazane zostało na obszarze prawa dyscyplinarnego właściwego dla policji, gdzie art. 135g ust. 2 zd. 1 ustawy z dnia 6 kwietnia 1990 r. o Policji stanowi, że obwinionego uważa się za niewinnego, dopóki wina jego nie zostanie udowodniona i stwierdzona prawomocnym orzeczeniem. 
stytucji RP zasadą godności człowieka, która jest prawem przyrodzonym i niezbywalnym. Gwarancja do bycia traktowanym jak osoba niewinna wyrażona została zarówno w Konstytucji RP, jak i w wiążących Polskę aktach prawa międzynarodowego ${ }^{17}$. Jest to jedna $\mathrm{z}$ kardynalnych zasad wyznaczających pozycję jednostki w społeczeństwie i jej relacje w stosunku do władzy. Analizując funkcjonowanie zasady domniemania niewinności na obszarze prawa dyscyplinarnego, należy zwrócić uwagę na wyrok Trybunału Konstytucyjnego z dnia 29 stycznia 2002 r. ${ }^{18}$, w którym TK uznał, że „uregulowanie domniemania niewinności w Konstytucji, wśród przepisów dotyczących wolności oraz praw człowieka i obywatela, oznacza rozszerzenie zakresu stosowania zasady poza ramy procesu karnego".

Pominięcie określenia zasady, na której opiera się odpowiedzialność w prawie dyscyplinarnym właściwym dla ABW i w konsekwencji nieuwzględnienie zasady domniemania niewinności, są pochodną generalnego mankamentu obecnych przepisów, objawiającego się w postaci braku uregulowania kwestii odpowiedniego stosowania w postępowaniu dyscyplinarnym regulacji prawa karnego materialnego ${ }^{19}$. W wyroku z dnia 5 listopada 2003 r. ${ }^{20}$ Sąd Najwyższy, analizując przepisy określające reżim dyscyplinarny właściwy dla sędziów sądów powszechnych, stwierdził, że brak jednoznacznego uregulowania zastosowania w postępowaniu dyscyplinarnym przepisów prawa karnego materialnego stanowi lukę rzeczywistą systemu prawnego, która musi być wypełniona zabiegami interpretacyjnymi. W przywołanym wyroku Sąd Najwyższy uznał, iż obowiązywanie w obszarze prawa dyscyplinarnego skodyfikowanej w art. $2 \$ 1$ pkt $1 \mathrm{kpk}$. zasady trafnej reakcji ${ }^{21}$ uzależnione jest od poszanowania $\mathrm{w}$ postępowaniu dyscyplinarnym naczelnych zasad prawa karnego. Zdaniem Sądu Najwyższego realizacja fundamentalnej zasady trafnej reakcji, która na obszarze prawa dyscyplinarnego przybiera postać reguły nakazującej, by do odpowiedzialności dyscyplinarnej pociągnięta została jedynie osoba, która dopuściła się czynu rodzącego odpowiedzialność dyscyplinarną, wymaga poszanowania podstawowych zasad prawa karnego. Niezbędne jest również odpowiednie stosowanie rozwiązań określających czas popełnienia czynu zabronionego, przepisów dotyczących

17 Zasada domniemania niewinności wyrażona została w art. 42 ust. 3 Konstytucji, w art. 14. Międzynarodowego Paktu Praw Obywatelskich i Politycznych otwartego do podpisu w Nowym Jorku dnia 19 grudnia 1966 r. (Dz.U. z 1977 r. nr 38, poz. 167) i w art. 6 Konwencji o Ochronie Praw Człowieka i Podstawowych Wolności sporządzonej w Rzymie dnia 4 listopada 1950 r. (Dz.U. z 1993 r. Nr 61, poz. 284).

18 Wyrok TK z dnia 29 stycznia 2002 r., K 19/01 (Dz.U. z 2002 r. Nr 10, poz. 107).

19 O potrzebie odpowiedniego stosowania prawa materialnego $w$ toku postępowań dyscyplinarnych zob. A. Herzog, Odpowiedzialność dyscyplinarna prokuratorów - co trzeba zmienić, „Prokuratura i Prawo” 2013, nr 12, s. 7; W. Kozielewicz, Stosowanie prawa karnego materialnego i procesowego w postępowaniu dyscyplinarnym w sprawach sędziów (zarys problematyki), (w:) L. Leszczyński, E. Skrętowicz, Z. Hołda (red.), W kręgu teorii i praktyki prawa karnego. Księga poświęcona pamięci Profesora Andrzeja Wąska, Lublin 2005, s. 464.

20 Wyrok SN z dnia 5 listopada 2003 r., SNO 67/03, Lex 471880.

21 Zasada trafnej reakcji obowiązuje również w prawie dyscyplinarnym właściwym dla ABW. § 53 rozporządzenia Prezesa Rady Ministrów z dnia 20 grudnia 2004 r. w sprawie udzielania wyróżnień i przeprowadzania postępowań dyscyplinarnych wobec funkcjonariuszy Agencji Bezpieczeństwa Wewnętrznego stwierdza, iż w sprawach nieuregulowanych $w$ rozporządzeniu, w zakresie postępowania dyscyplinarnego, stosuje się odpowiednio przepisy ustawy z dnia 6 czerwca 1997 r. - Kodeks postępowania karnego. 
formy czynu i formy jego popełnienia oraz zasad określających okoliczności wyłączające odpowiedzialność. Kierując się znaczeniem właściwego stosowania przepisów prawa karnego w obszarze prawa dyscyplinarnego, Sąd Najwyższy wskazał sposób wykorzystywania regulacji materialnoprawnych w związku ze sprawą dyscyplinarną, stwierdzając, że „w toku postępowania dyscyplinarnego należy sięgać - na zasadzie analogii iuris - do rozwiązań przewidzianych w kodeksie karnym. Rzecz jasna, przepisy prawa karnego materialnego muszą podlegać w postępowaniu dyscyplinarnym stosowaniu odpowiedniemu, a więc polegającemu na: a) stosowaniu wprost, b) stosowaniu z odpowiednimi modyfikacjami lub c) odmowie ich zastosowania ze względu na określone różnice, $i$ to przy zachowaniu szczególnej ostrożności”22. Konieczność odpowiedniego posługiwania się przepisami prawa karnego materialnego w ramach postępowań dyscyplinarnych potwierdzona została przez Sąd Najwyższy w wyroku z dnia 14 lipca 2009 r. $^{23}$. W wyroku tym Sąd Najwyższy trafnie zauważył, że kwestia stosowania przepisów prawa karnego materialnego w ramach postępowań dyscyplinarnych nie jawi się jako oczywista. Uwzględniając gwarancyjny charakter prawa karnego i przewidzianych w nim konstrukcji, podniesiony przez Sąd Najwyższy brak oczywistości w przedmiocie sięgania po te regulacje na obszarze reżimu dyscyplinarnego może mieć daleko idące, negatywne skutki, wobec czego nowe regulacje dotyczące tej problematyki winny być jednoznaczne.

Swoistą pochodną niedostatecznego uwzględnienia konstrukcji prawa karnego w prawie dyscyplinarnym właściwym dla ABW jest zamieszczony w art. 146 ustawy o ABW katalog kar dyscyplinarnych. Jako nieadekwatne uznać należy zakwalifikowanie ostrzeżenia o niepełnej przydatności do służby jako kary najcięższej, łagodniejszej jedynie od sankcji wydalenia ze służby. Wydaje się, że karą znacznie bardziej dotkliwą jest kara pozbawienia stopnia oficerskiego. Kara ta swoją surowością przewyższa ostrzeżenie o niepełnej przydatności do służby nie tylko w wymiarze honorowym $^{24}$, ale dodatkowo wiąże się z bardziej dolegliwymi skutkami finansowymi. Zgodnie z załącznikiem do rozporządzenia Prezesa Rady Ministrów z dnia 7 października 2002 r. w sprawie dodatków do uposażenia funkcjonariuszy Agencji Bez-

W przedmiocie odpowiedniego stosowania przepisów kodeksu postępowania karnego w ramach postępowania dyscyplinarnego podobne zapatrywanie wyraził SN w Uchwale Składu Siedmiu Sędziów z dnia 28 września 2006 r., I Kzp 8/06, Lex 193136, OSNKW 2006/10/87.

23 Wyrok SN z dnia 14 lipca 2009 r., SNO 42/ 09, Lex 575812, OSNKW 2010/5/44. Za dopuszczalnością odpowiedniego stosowania prawa karnego materialnego na obszarze postępowania dyscyplinarnego wypowiedział się również WSA w Warszawie, który w wyroku z dnia 4 października 2006 r., II SA/Wa, 908/06, Lex 284495 wyraził pogląd, że „nie ma powodów, aby dla potrzeb postępowania dyscyplinarnego prowadzonego przeciwko funkcjonariuszowi Policji stosować inne interpretacje winy nieumyślnej niż ta, która jest ustalona w prawie karnym". Pewne zastrzeżenia do tego orzeczenia wyraził D. Korczyński, Wina jako przesłanka..., op. cit., s. 15-16.

24 Zauważyć należy, że pozbawienie stopnia oficerskiego jest również jednym ze skutków wymierzenia środka karnego w postaci pozbawienia praw publicznych, który to środek karny stosownie do art. $40 \S 2$ kk. może być orzeczony w razie skazania na karę pozbawienia wolności na czas nie krótszy od lat 3 za przestępstwo popełnione w wyniku motywacji zasługującej na szczególne potępienie. W doktrynie podkreśla się, że środek karny w postaci pozbawienia praw publicznych wywodzi się z tych kar, które skutkowały pozbawieniem opieki prawnej, wypędzeniem, utratą czci i praw. W kodeksie z roku 1932 odpowiednikiem pozbawienia praw publicznych były kary dodatkowe w postaci utraty praw obywatelskich i obywatelskich prawa honorowych. D. Szeleszczuk, Komentarz do art. 40, (w:) A. Grześkowiak, K. Wiak (red.), Kodeks Karny. Komentarz. Warszawa 2012, s. 301. 
pieczeństwa Wewnętrznego ${ }^{25}$ dodatek za stopień służbowy szeregowego wynosi 600 zł, natomiast dodatek za najniższy stopień w korpusie oficerów, to jest dodatek za stopień podporucznika, wynosi $980 \mathrm{zł}$. W przypadku wyższych stopni oficerskich kwoty dodatków są jeszcze większe. Kwota dodatku dla pułkownika to $1160 \mathrm{zł}$, natomiast generał brygady otrzymuje 1270 zł. Równocześnie dojście do stopnia oficerskiego w normalnym trybie zajmuje od ośmiu do dziesięciu lat.

Analizując prawo dyscyplinarne właściwe dla ABW w kontekście koncepcji rzetelnego procesu, należy także zwrócić uwagę na jeden $\mathrm{z}$ fundamentalnych elementów tej idei, jaką stanowi prawo do skutecznego środka odwoławczego i jego realizacja w ramach reżimu dyscyplinarnego. Zgodnie z $\$ 7$ pkt 2 rozporządzenia Prezesa Rady Ministrów z dnia 20 grudnia 2004 r. do wymierzenia kary dyscyplinarnej wyznaczenia na niższe stanowisko służbowe, kary ostrzeżenia o niepełnej przydatności do służby i najsurowszej kary dyscyplinarnej w postaci wydalenia ze służby właściwy jest Szef ABW. Równocześnie $\$ 32$ ust. 4 stanowi, iż od wydanego w postępowaniu dyscyplinarnym orzeczenia Szefa Agencji Bezpieczeństwa Wewnętrznego odwołanie nie przysługuje, a ukarany dysponuje jedynie prawem zwrócenia się o ponowne rozpoznanie sprawy. W tym miejscu zauważyć należy, że represyjny charakter odpowiedzialności dyscyplinarnej powoduje, iż stricte administracyjny wniosek o ponowne rozpatrzenie sprawy ${ }^{26}$ nie stanowi adekwatnego instrumentu ochrony praw w obszarze prawa dyscyplinarnego. Przy okazji gruntownej reformy służb specjalnych warto również poważnie rozważyć zgłaszane w doktrynie postulaty ${ }^{27}$ o przekazaniu orzecznictwa dyscyplinarnego z sądów administracyjnych do sądów powszechnych i pełniejszemu podporządkowaniu postępowania dyscyplinarnego prawu karnemu procesowemu ${ }^{28}$. Za pozostawieniem spraw z zakresu odpowiedzialności dyscyplinarnej w zakresie kompetencji sądów administracyjnych przemawia wzgląd na formalny charakter rozstrzygnięcia dyscyplinarnego, które przybiera postać decyzji administracyjnej $^{29}$, jak i administracyjny, cechujący się znacznym stopniem podporządkowania i nierówności, charakter powstającego w drodze mianowania stosunku służby ${ }^{30}$. Z kolei do podporządkowania spraw dyscyplinarnych właściwości sądów

Rozporządzenie Prezesa Rady Ministrów z dnia 7 października 2002 r. w sprawie dodatków do uposażenia funkcjonariuszy Agencji Bezpieczeństwa Wewnętrznego (tekst jedn. Dz.U. z 2016 r., poz. 1025). (red.), Kodeks postępowania administracyjnego: Komentarz, Tom I do art. 1-103, Warszawa 2010, s. 185-187. Wypowiedzi tej treści padały także w trakcie ogólnopolskiej konferencji „Modele postępowania dyscyplinarnego w świetle zasad rzetelnego procesu" zorganizowanej przez Katedrę Postępowania Karnego Wydziału Prawa Uniwersytetu w Białymstoku w dniu 17 marca 2014 r.

28 S. Maj, Odpowiedzialność dyscyplinarna..., op. cit., s. 41.

29 O związkach materialnego charakteru sprawy z trybem jej rozpoznawania zob. T. Romer, Właściwość sądów administracyjnych i sądów powszechnych w sprawach z zakresu prawa pracy, (w:) M. Błachucki, T. Górzyńska (red.), Aktualne problemy rozgraniczania właściwości sądów administracyjnych i sądów powszechnych, Warszawa 2011, s. 59 i 64.

30 Pogląd, że charakter stosunku prawnego stanowi argument za poddaniem sporów wynikających z tego stosunku odpowiedniemu rodzajowi postępowania wyraża m.in. W. Sanetra, Właściwość sądów powszechnych (sądów pracy i ubezpieczeń społecznych) i sądów administracyjnych w sprawach z zakresu ubezpieczeń społecznych, (w:) M. Błachucki, T. Górzyńska (red.), Aktualne problemy..., op. cit., s. 77. Rzeczywistą naturę sporu przy określaniu właściwej procedury do jego rozstrzygnięcia nakazuje uwzględnić też M. Jaśkowska, Konstytucyjno- 
powszechnych skłania przede wszystkim represyjny charakter odpowiedzialności dyscyplinarnej. Uwzględniając przywołane argumenty należy stwierdzić, że podkreślony cel postępowania dyscyplinarnego, jakim jest wymierzenie kary za popełnione przewinienie, wydaje się być argumentem decydującym dla określenia właściwej procedury dla rozstrzygnięcia sprawy dyscyplinarnej. Odpowiedzialność dyscyplinarna, choć wyrasta ze służbowego stosunku administracyjnego, ostatecznie usamodzielnia się i poprzez swoje nakierowanie na karę staje się bardziej zbliżona do stosunku karnoprawnego. Wobec czego finalna decyzja w przedmiocie odpowiedzialności dyscyplinarnej winna zapadać w oparciu o przepisy postępowania karnego, stosowane przez sąd powszechny. Takie rozwiązanie, uwzględniające autonomiczny charakter odpowiedzialności dyscyplinarnej, pozwoli na jej rozstrzyganie za pomocą procedury lepiej do tego dostosowanej i zapewniającej więcej gwarancji.

Podsumowując dokonane uwagi dotyczące wybranych rozwiązań prawa dyscyplinarnego właściwego dla ABW, dla wyrażenia których inspiracją jest przygotowywana przebudowa systemu polskich służb specjalnych, uznać należy, że funkcjonujący obecnie reżim dyscyplinarny w ABW jest regulacją daleką od doskonałości ${ }^{31}$. W związku z tym należy postulować, aby ustawodawca przy okazji tworzenia nowych regulacji dotyczących służb specjalnych, konstruując przepisy dyscyplinarne, poświęcił więcej uwagi wymogom wypływającym z koncepcji rzetelnego procesu, albowiem jedynie właściwe odniesienie się do idei fair trial pozwoli na usunięcie obecnie istniejących niedociągnięć prawa dyscyplinarnego i dostosowanie go do standardów, jakie winna spełniać regulacja o charakterze represyjnym w demokratycznym państwie prawa.

\section{BIBLIOGRAFIA}

Brzozowski A., Safjan M., Skowrońska-Bocian E., Zobowiązania, Wydanie 9., Warszawa 2004.

Cieślak M., Polskie prawo karne. Zarys systemowego ujęcia, Warszawa 1994.

Gardocki L., Prawnokarna problematyka sędziowskiej odpowiedzialności dyscyplinarnej, (w:) J. Giezek (red.), Przestępstwo - kara - polityka kryminalna. Problemy tworzenia i funkcjonowania prawa. Księga jubileuszowa z okazji 70. rocznicy urodzin Profesora Tomasza Kaczmarka, Kraków 2006.

Gryz J., Teoretyczne aspekty funkcjonowania służb specjalnych RP, „Studia i materiały” 2012, nr 1.

prawne podstawy sądownictwa powszechnego i administracyjnego oraz delimitacja właściwości tych sądów, (w:) M. Błachucki, T. Górzyńska (red.), Aktualne problemy..., op. cit., s. 26. W tym miejscu należy nadmienić, że kierując się przywołanym postulatem Autorka wyraża wątpliwości co do poddania spraw dyscyplinarnych właściwości sądów administracyjnych, ibidem, s. 29.

31 Oprócz omówionych w prezentowanym tekście wątpliwości, w literaturze przedmiotu podnoszone są również inne problemy dotyczące prawa dyscyplinarnego służb mundurowych. Szereg pytań co do poszczególnych rozwiązań reżimów dyscyplinarnych służb mundurowych stawia S. Maj, Odpowiedzialność dyscyplinarna..., op. cit, s. 41. 
Herzog A., Odpowiedzialność dyscyplinarna prokuratorów - co trzeba zmienić. „Prokuratura i Prawo” 2013, nr 12.

Jaśkowska M., Konstytucyjnoprawne podstawy sądownictwa powszechnego i administracyjnego oraz delimitacja właściwości tych sądów, (w:) M. Błachucki, T. Górzyńska (red.), Aktualne problemy rozgraniczania właściwości sądów administracyjnych i sądów powszechnych, Warszawa 2011.

Jóźwiak P., Instytucja ułaskawienia - refleksje na płaszczyźnie odpowiedzialności dyscyplinarnej w służbach mundurowych, (w:) P. Jóźwiak, K. Opaliński (red.), Węzłowe problemy prawa dyscyplinarnego w służbach mundurowych. II seminarium z cyklu „Odpowiedzialność dyscyplinarna w służbach mundurowych”, „Biblioteczka Kwartalnika Prawno-Kryminalistycznego” 2012, nr 2.

Korczyński D., Wina, jako przesłanka odpowiedzialności dyscyplinarnej funkcjonariuszy służb mundurowych, (w:) P. Jóźwiak, K. Opaliński (red.), Węzłowe problemy prawa dyscyplinarnego w służbach mundurowych. II seminarium z cyklu „Odpowiedzialność dyscyplinarna w służbach mundurowych”, „Biblioteczka Kwartalnika Prawno-Kryminalistycznego” 2012, nr 2.

Kozielewicz W., Stosowanie prawa karnego materialnego i procesowego w postępowaniu dyscyplinarnym w sprawach sędziów (zarys problematyki), (w:) L. Leszczyński, E. Skrętowicz, Z. Hołda (red.), W kręgu teorii i praktyki prawa karnego. Księga poświęcona pamięci Profesora Andrzeja Wąska, Lublin 2005.

Łaszczyca G., (w:) G. Łaszczyca, Cz. Martysz, A. Matan (red.), Kodeks postępowania administracyjnego: Komentarz. Tom I do art. 1-103, wyd. 3, Warszawa 2010.

Maj S., Odpowiedzialność dyscyplinarna w służbach mundurowych. Możliwość uchwalenia wspólnej procedury, (w:) P. Jóźwiak, K. Opaliński (red.), Węzłowe problemy prawa dyscyplinarnego w służbach mundurowych. II seminarium z cyklu „Odpowiedzialność dyscyplinarna w służbach mundurowych”, „Biblioteczka Kwartalnika Prawno-Kryminalistycznego” 2012, nr 2.

Pożaroszczyk D., Prawne mechanizmy służące zapewnieniu przestrzegania praworządności w wojskowych służbach specjalnych, (w:) M. Karpiuk, M. Czuryk (red.), Prawo wojskowe, Warszawa 2015.

Romer T., Właściwość sądów administracyjnych i sądów powszechnych w sprawach z zakresu prawa pracy, (w:) M. Błachucki, T. Górzyńska (red.), Aktualne problemy rozgraniczania właściwości sądów administracyjnych i sądów powszechnych, Warszawa 2011.

Smidt W.K., Poppe U., Krieger W., Müller-Enbergs H. (Hg.), Geheimhaltung und Transparenz: demokratische Kontrolle der Geheimdienste im internationalen Vergleich, Berlin - Münster 2007.

Szeleszczuk D., Komentarz do art. 40, (w:) A. Grześkowiak, K. Wiak (red.), Kodeks karny. Komentarz, Warszawa 2012.

Taracha A., Czynności operacyjno-rozpoznawcze aspekty kryminalistyczne i prawnodowodowe, Lublin 2006.

Sanetra W., Właściwość sądów powszechnych (sądów pracy i ubezpieczeń społecznych) i sądów administracyjnych w sprawach z zakresu ubezpieczeń społecznych, (w:) M. Błachucki, T. Górzyńska (red.), Aktualne problemy rozgraniczania właściwości sądów administracyjnych i sądów powszechnych, Warszawa 2011. 